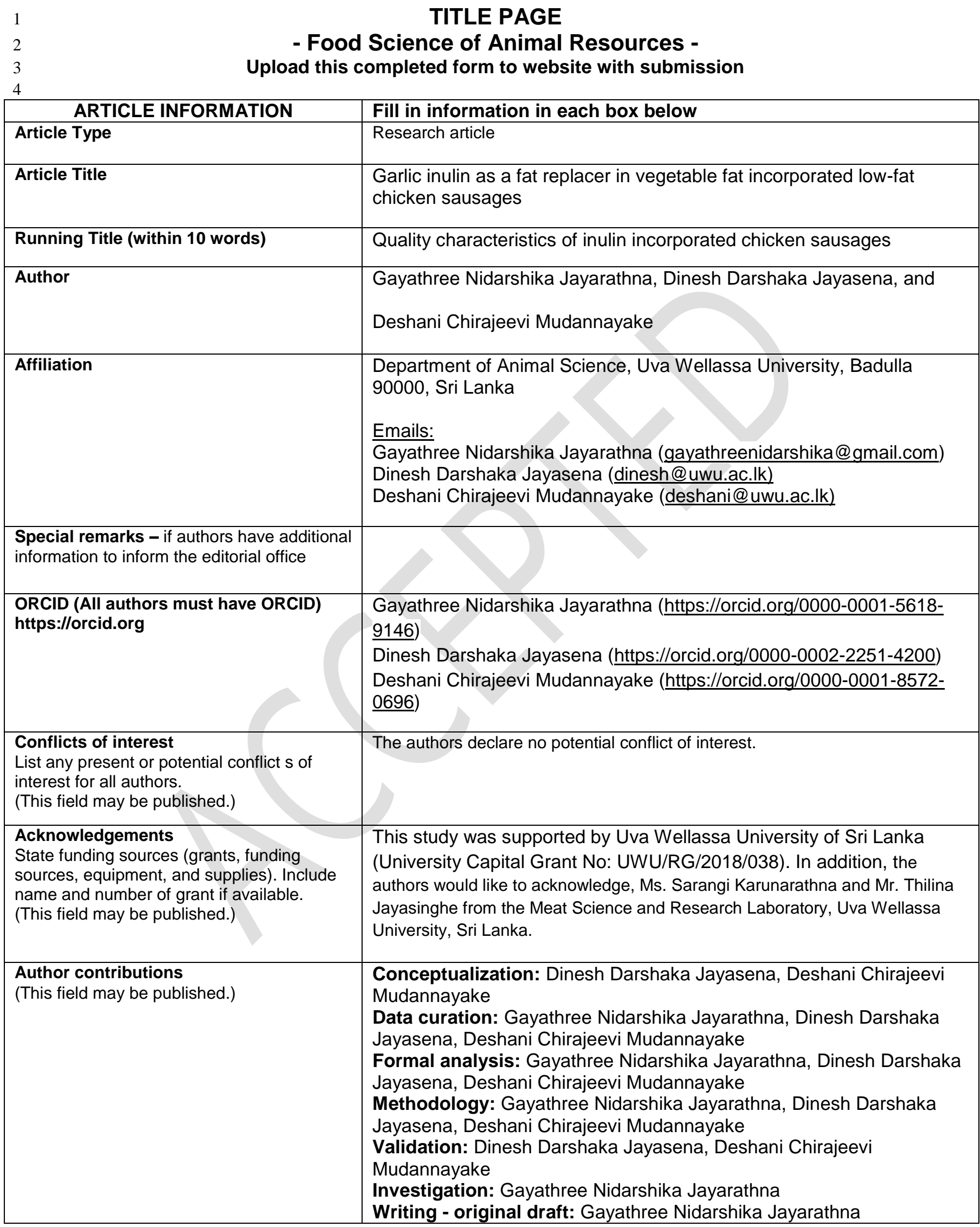




\begin{tabular}{|l|l|}
\hline & $\begin{array}{l}\text { Writing - review \& editing: Gayathree Nidarshika Jayarathna, Dinesh } \\
\text { Darshaka Jayasena, Deshani Chirajeevi Mudannayake }\end{array}$ \\
\hline $\begin{array}{l}\text { Ethics approval (IRB/IACUC) } \\
\text { (This field may be published.) }\end{array}$ & $\begin{array}{l}\text { The design of the sensory evaluation conducted in this study was reviewed and } \\
\text { approved by the Research Ethics Review Committee of Uva Wellassa } \\
\text { University (No. UWU/REC/2021/003). }\end{array}$ \\
\hline
\end{tabular}

5

6

7 AUTHOR CONTACT INFORMATION

\begin{tabular}{|c|c|}
\hline $\begin{array}{l}\text { For the corresponding author } \\
\text { (responsible for correspondence, } \\
\text { proofreading, and reprints) }\end{array}$ & Fill in information in each box below \\
\hline First name, middle initial, last name & Deshani Chirajeevi Mudannayake \\
\hline $\begin{array}{l}\text { Email address - this is where your proofs } \\
\text { will be sent }\end{array}$ & deshani@uwu.ac.lk \\
\hline Secondary Email address & deshani m@yahoo.com \\
\hline Postal address & $\begin{array}{l}\text { Department of Animal Science, Uva Wellassa University, Badulla } \\
90000 \text {, Sri Lanka }\end{array}$ \\
\hline Cell phone number & $+94-71-8169273$ \\
\hline Office phone number & $+94-55-2226580$ \\
\hline Fax number & $+94-55-2226672$ \\
\hline
\end{tabular}




\section{Garlic inulin as a fat replacer in vegetable fat incorporated low-fat chicken sausages}

\section{Abstract}

Inulin is a non-digestible carbohydrate and a prebiotic that can also act as a fat replacer in various foods. This study examined the effect of replacing vegetable oil with garlic inulin on the quality traits of chicken sausages. Water-based inulin gels were prepared using garlic inulin or commercial inulin to imitate fats in chicken sausages. Chicken sausages were prepared separately replacing vegetable oil with water-based inulin gels to reach final inulin percentages of 1,2 , and $3(\mathrm{w} / \mathrm{w})$. The control was prepared using $3 \%(\mathrm{w} / \mathrm{w})$ vegetable oil with no inulin. The physicochemical properties and thiobarbituric acid reactive substance (TBARS) value of prepared sausages were analyzed over 28 -d frozen storage. Sausages with $2 \%$ garlic inulin recorded higher flavour and overall acceptability scores $(p<0.05)$. Ash, moisture, and protein contents of the sausages were increased with increasing levels of inulin while fat content was reduced from $13.67 \%$ (control) to $4.47-4.85 \%(p<0.05)$ in $3 \%$ inulin-incorporated products. Sausages incorporated with $2 \%$ inulin had lower lightness $\left(\mathrm{L}^{*}\right)$ values than the control $(p<0.05)$. Water holding capacity was similar $(p>0.05)$ among the samples. During storage $\mathrm{L}^{*}$ value, $\mathrm{pH}$, and water holding capacity decreased while redness $\left(\mathrm{a}^{*}\right)$ and yellowness $\left(\mathrm{b}^{*}\right)$ values increased in all the samples. In addition, TBARS values were increased during the storage in all samples within the acceptable limits. In conclusion, garlic inulin can be used successfully as a fat substitute in sausages without altering meat quality parameters.

Keywords: Fat substitute, Garlic, Meat quality, Prebiotic, TBARS 


\section{Introduction}

Meat as a nutritionally dense food of animal origin is vital for a healthy and well balanced diet. Meat and meat products have a unique role in optimal human growth and development throughout the history (Higgs, 2000; Pereira and Vicente, 2013). These are rich in protein of high biological value, in particular essential amino acids such as isoleucine, leucine, lysine, methionine, tryptophan, valine, and phenylalanine, and micro nutrients like vitamin $\mathrm{B}_{12}$, vitamin A, folic acid, iron, selenium, zinc, and copper that human body needs to function properly (Pereira and Vicente, 2013; Verbeke et al., 2010). Despite the nutritional value, meat and meat products are considered disease-promoting food primarily due to the fat content (Pereira and Vicente, 2013) that is originally present and/or added during processing including vegetable oil. Some epidemiological data has revealed that prolonged intake of high fat meat products is directly associated with the occurrence of several chronic diseases such as cancer and cardiovascular diseases (Domingo and Nadal, 2017; Han and Bertram, 2017).

Fat as a vital ingredient in the production of meat products contributes to the flavor, texture, mouth feel, and appearance of the end products (Alaei et al., 2018; Cáceres et al., 2004; Luisa García et al., 2006). Commercial sausage manufacturers in Sri Lanka use vegetable oil as a main fat source in their products. Vegetable oils are composed mainly of triacylglycerols (around 95\%) along with some free fatty acids, monoacylglycerols, and diacylglycerols and the remainder comprises of minor components which include phospholipids, free and esterified sterols, triterpene alcohols, tocopherols and tocotrienols, pigments, and hydrocarbons (Oswell et al., 2005). However, consumer demand for healthier meat products with lower fat, cholesterol, nitrates, and calories, and higher health promoting components has increased over the last few 
years (Wolk, 2017). Numerous extensive approaches have been proposed to reduce fat content of meat products by incorporating health promoting ingredients such as dietary fibers while retaining the sensory and organoleptic properties.

Addition of dietary fibers such as inulin into meat products has become an emerging trend in recent years due to their potential health benefits including inhibiting colon tumor growth, lowering the risk of coronary heart diseases, preventing cholesterol absorption and reducing obesity risk (Hathwar et al., 2012). Inulin is being widely applied in the food industry either individually or combined with other related ingredients as a prebiotic, dietary fiber, low calorie sweetener, fat replacer, gelling agent, viscosity modifier, and a texture modifying ingredient in various foods (Melilli et al., 2021; Mensink et al., 2015). In aqueous systems, upon vigorous mixing and consequent cooling, inulin forms a smooth gelling structure which provides a combination of creamier and juicier mouth feel to the end product which can potentially replace fat, without altering its rheological properties but resembling the mouth feel of fat in lowfat meat products upon incorporation (Franck, 2002; Mudannayake et al., 2015b). Hence, it can possibly be used as a fat substitute in formulation of low fat meat products (Illippangama et al., 2022) with a low calorie content of about 1-1.5 kcal per gram (Weiss et al., 2010).

Inulin naturally occurs in tubers, rhizomes, and bulbs of plants such as chicory (Cichorium intybus), garlic (Allium sativum), Jerusalem artichoke (Helianthus tuberosus), leeks (Allium porrum), dahlia (Dahlia pinnata), onion (Allium cepa), asparagus (Asparagus falcaus), etc (Mudannayake et al., 2015a). The commercial production of inulin is primarily based on two plant species, C. intybus and $H$. tuberosus at present and limited to European countries (Moongngarm et al., 2011). The use of inulin as an ingredient in food industry is very limited in Sri Lanka due to its high cost. Garlic belongs to the family of Amaryllidaceae and Genus Allium. 
Garlic (A. sativum) bulb is found as a rich source of inulin $(18-19 \mathrm{~g} / 100 \mathrm{~g}$ fresh weigh; Mudannayake et al., 2015a) and is available in Sri Lanka. Garlic can be used to extract inulin which potentially delivers enhanced flavors and organoleptic properties in food products.

Vegetable oil has been successfully replaced with inulin in the formulation of emulsiontype chicken sausages (Alaei et al., 2018; Berizi et al., 2017). Guedes-Oliveira et al. (2019) produced reduced fat lamb patties incorporating vegetable fat with inulin. Furthermore, Menegas et al. (2013) produced dry-fermented chicken sausage replacing corn oil with inulin for the enhancement of physicochemical, microbiological, and textural characteristics. However, literature reveals that scientific data on effect of garlic inulin as a fat substitute on quality of meat and meat products are scant. Therefore, this study examined the extraction of inulin from garlic and the effects of adding extracted garlic inulin and commercial (chicory) inulin as partial fat replacers on physicochemical, sensory, and textural characteristics of vegetable fat incorporated chicken sausages.

\section{Materials and Methods}

Commercial chicory inulin (BENEO Orafti ${ }^{\circledR}$ ) was purchased from DPO Lanka (Pvt) Ltd, Colombo, Sri Lanka and garlic inulin was extracted from garlic bulbs using hot water extraction, vacuum evaporation and subsequent spray drying as described by Mudannayake et al. (2015b) with slight modifications. The ingredients employed to prepare the sausage formulations, such as chicken breast meat, vegetable oil, wheat flour, chili powder, salt, pepper, onion, cardamom and cinnamon were purchased from a local grocery store. 


\section{Extraction of inulin from garlic}

Garlic bulbs (A. sativum) were first peeled, cleaned and washed thoroughly with water and subsequently cut into small slices to have $3 \mathrm{~mm}$ thickness. Sliced garlic was then blanched in boiling water, acidified with ascorbic acid $(0.1 \% \mathrm{w} / \mathrm{w})$ for 1 to $2 \mathrm{~min}$, mixed with potable water $(1: 10 \mathrm{~g} / \mathrm{mL})$ and kept at $80 \pm 5^{\circ} \mathrm{C}$ for 50 min with frequent stirring in a double-water-jacketed pan on a stove. Then the mixture was filtered through 4 layers of muslin cloth and the residue was weighed and re-extracted one more time following the same procedure. Both extracts were combined together and concentrated to a brix value of approximately $8^{\circ}$ at $60^{\circ} \mathrm{C}$ using a rotavapor (Model: 1000282711, BUCHI Labortechnik AG, China) equipped with evaporator flask, receiving flask, recirculating chiller, and vacuum pump. The concentrated extracts were finally spray dried (Model: 005-1116-FD, SOLTEC ${ }^{\circledR}$, Malaysia) at a feed rate of $2.5 \mathrm{~L} / \mathrm{h}$, air flow of $110 \mathrm{~kg} / \mathrm{h}$, and inlet and outlet temperatures of 60 and $200^{\circ} \mathrm{C}$ to obtain a light colour fine powder, respectively.

\section{Fourier transform infrared spectroscopy (FT-IR)}

The chemical characterization of extracted garlic inulin and commercially available chicory inulin powders was conducted separately using Fourier-transform infrared (FT-IR) (Bruker FTIR spectrophotometer, Bruker Optik GmbH, Germany) equipped with an OPUS 7.5 FT-IR software against a $\mathrm{KBr}$ background. Approximately $2 \mathrm{mg}$ of each powder were milled separately with $200 \mathrm{mg}$ of $\mathrm{KBr}$ using a clean motor and pestle and pressed into pellets manually. The 
117 prepared clear KBr-inulin pellets were analyzed in the FT-IR. A spectral range of $4000-400 \mathrm{~cm}^{-1}$ at a resolution of $4 \mathrm{~cm}^{-1}$ and 32 scans for each spectrum were used (Grube et al., 2002).

119

\section{Determination of inulin content}

Inulin content of commercial inulin and extracted garlic inulin powders were analyzed separately according to enzymatic spectrophotometric method (AOAC 999.03) as described by AOAC (2005) using the Megazyme fructan assay kit (Megazyme, Ireland), which contained sucrase, fructanase, fuctan control, sucrose control and D-Fructose standard (Mudannayake et al., 2015a). Briefly, $1 \mathrm{~g}$ of inulin sample was put into a conical flask filled with $80 \mathrm{~mL}$ of hot distilled water $\left(\sim 70^{\circ} \mathrm{C}\right)$. The conical flasks were covered with parafilm and placed on a shaking water bath at a constant temperature $\left(85 \pm 2^{\circ} \mathrm{C}\right)$ to extract fructans and sugars. Sample extract was allowed to cool to room temperature and the volume was adjusted to $100 \mathrm{~mL}$ with distilled water and it was mixed well. Finally, the mixture was filtered through a filter paper (No.4 Whatman International Ltd., Maidstone, England) and the inulin content of the extract was determined as described by McCleary et al. (2000). The inulin content of each powder was calculated using the following formula:

$$
\text { Inulin } \%=\Delta \mathrm{A} \times \mathrm{F} \times \frac{\mathrm{V}}{\mathrm{W}} \times 2.48
$$

where $\Delta \mathrm{A}=$ sample absorbance-sample blank absorbance (both read against the reagent blank), $\mathrm{F}=$ factor to convert absorbance values to $\mu \mathrm{g}$ of fructose $[(54.5 \mu \mathrm{g}$ of $\mathrm{D}$-Fructose)/ (absorbance for $54.5 \mu \mathrm{g}$ of D-Fructose)],

$\mathrm{V}=$ volume $(\mathrm{mL})$ of extract used, and W=weight $(\mathrm{mg})$ of sample extracted. 


\section{Preparation of water based inulin gel}

The water based inulin gel was prepared using $40 \%$ of inulin $(\mathrm{w} / \mathrm{w}), 58 \%$ of water $(\mathrm{w} / \mathrm{w})$ and $2 \%$ of soya lecithin $(\mathrm{w} / \mathrm{w})$ (Kim and Wang, 2001). During the preparation of inulin gel, the aqueous solution of inulin was heated to $85^{\circ} \mathrm{C}$ with continuous mechanical stirring for $20 \mathrm{~min}$, mixed with soy lecithin, allowed to cool to room temperature and refrigerated $\left(5^{\circ} \mathrm{C}\right)$ for $24 \mathrm{~h}$ (Mudannayake et al., 2015a). After $24 \mathrm{~h}$, the resultant water based stable inulin gel was incorporated into meat batter to reach 1,2 , and $3 \%(\mathrm{w} / \mathrm{w})$ total inulin levels in the product.

\section{Experiment-1}

Experiment-1 was conducted to select the best level of inulin for manufacture of low-fat chicken sausages without altering the desired quality characteristics.

\section{Formulations}

Seven formulations of chicken sausages were prepared for the study with different percentages of laboratory prepared garlic inulin or commercial chicory inulin according to commercial guidelines to test the replacement of vegetable oil with garlic or commercial chicory inulin. The treatments and amounts of the ingredients used in each treatment in production of low-fat chicken sausages are given in Table 1. Chicken meat was first minced in a mincer (HR2726, PHILIPS, China) and the remaining ingredients (Table 1) were added and mixed thoroughly. The meat batter was then stuffed in cellulose casing and links were formed. The products were then cooked until the core temperature of the product reached to $72{ }^{\circ} \mathrm{C}$. After heat treatment, the products were cooled and casings were removed. Finally, the products were vacuum packed (DZ500-2D, China) and stored under frozen condition $\left(-18^{\circ} \mathrm{C}\right)$ until further 
analysis. The experimental units were $1.5 \mathrm{~kg}$, in triplicate, and at three different time periods (three lots).

\section{Proximate composition}

Proximate composition of inulin powders and sausages samples was determined following the method of AOAC (2016). Briefly, moisture content (AOAC 950.46) was measured by drying each sample $(3 \mathrm{~g})$ in an aluminum dish at $104^{\circ} \mathrm{C}$ for $15 \mathrm{~h}$ (DHG-9145A, Zenith Lab Co. Ltd., Changzhou, China). Crude protein content (AOAC 928.08) was measured using the Kjeldahl method (DNP-3000, RAYPA, Barcelona, Spain). Crude protein content was calculated by multiplying the amount of nitrogen by a factor of 6.25. Crude fat content (AOAC 960.39) was measured using the Soxhlet extraction system (EME60250/CEB, Electrothermal, Staffordshire, UK). Crude ash content (AOAC 923.03) was determined by igniting each sample (2 g) in muffle furnace (HD-230, Hobersal, Barcelona, Spain) at $600^{\circ} \mathrm{C}$ overnight.

\section{Sensory evaluation}

The design of the sensory evaluation for cooked sausages was reviewed and approved by the Research Ethics Review Committee of Uva Wellassa University (No. UWU/REC/2021/003). Sensory evaluation of cooked sausages was performed with a panel of 30 untrained panelists in individual booths as described by Menegas et al. (2013). Sausage samples were first heated using a sausage griller (SG 9, ASAIN, Zhengzhou Ohfu Ind. Ent. Co. Ltd, China) just before the evaluation and prepared to uniform size $(1.5 \mathrm{~cm} \times 2 \mathrm{~cm})$. Coded sausage samples were then evaluated for appearance, texture, odour, flavour, fatty flavour, colour and overall acceptability using a 9-point hedonic scale (9-like extremely, 8-like very much, 7-like moderately, 6-like 
185

186

187

188

189

190

191

192

193

194

195

196

197

198

199

200

201

202

203

204

205

206

slightly, 5-neither like nor dislike, 4-dislike slightly, 3-dislike moderately, 2-dislike very much, 1-dislike extremely). Drinking water at room temperature was provided to rinse the mouth prior to and between sample evaluations.

\section{Experiment-2}

The best formulations from Experiment-1 were selected based on the results of sensory evaluation for determination of meat quality parameters during a 28-d frozen storage. Prior to analysis, samples were thawed by packing them in a clean leak-proof package and submerging in a container of clean tap water at room temperature, changing the water every $30 \mathrm{~min}$.

\section{Determination of $\mathrm{pH}$ value}

Each meat sample $(1 \mathrm{~g})$ was homogenized with $9 \mathrm{~mL}$ of distilled water for $60 \mathrm{~s}$ by using a homogenizer (Ika Laboratory Equipment, Korea) and filtered through a filter paper (No.4 Whatman International Ltd., Maidstone, England). The $\mathrm{pH}$ value of each filtrate was determined with a $\mathrm{pH}$ meter ( $\mathrm{pH} 700$, Eutech instruments, Singapore) after calibration using buffers $(\mathrm{pH}$ $4.01,7.00$ and 10.01) at room temperature.

(a)

al. (2010). Sausage samples $(2.00 \pm 0.10 \mathrm{~g})$ were carefully placed between two pieces of filter papers (No. 4; Whatman International Ltd, Maidstone, England) on acrylic plates and left under a 10-kg weight for 5 min separately. After recording the final weight of each sample, WHC was 
calculated using the following equation, where $W i$ and $W f$ are the initial and final weights $(\mathrm{g})$ of sample, respectively.

$$
\text { WHC }(\%)=100-\left[\frac{(W i-W f) \times 100}{W i}\right]
$$

\section{Determination of colour values}

The colour values of minced chicken sausages were measured using a colorimeter (CR-410, Konica Minolta, NIC., Japan) which was calibrated against a white reference tile (No. 20433045, $\mathrm{Y}=85.7, \mathrm{x}=0.3170$ and $\mathrm{y}=0.3242$, Konica Minolta, NIC., Japan). The average of three repeated measurements in each minced sample was used for the determination of the values of lightness (CIE L*), redness (CIE a*), and yellowness (CIE b*).

\section{Determination of lipid oxidation}

Lipid oxidation of sausage samples were evaluated by the determination of 2-thiobarbituric acid relative substances (TBARS) values as described in Lee et al. (2021) with some modifications. Each sample $(5 \mathrm{~g})$ was homogenized in $15 \mathrm{~mL}$ of deionized water using a homogenizer (D-500, Velp Scientifica, Usmate, Italy) at 14,000 rpm for $30 \mathrm{~s}$. Butylated hydroxytoluene (BHT; $50-\mu \mathrm{L})(7.2 \% \mathrm{w} / \mathrm{v}$ in ethanol) and thiobarbituric acid/trichloroacetic acid solution (20 mM TBA and 15\% [w/v] TCA; $2 \mathrm{~mL})$ were added to the homogenate $(1 \mathrm{~mL})$ and vortexed for $30 \mathrm{~s}$. The mixture was then incubated in a water bath (YCW-010E, Gemmy Industrial Corporation, Taipei, Taiwan) at $90^{\circ} \mathrm{C}$ for $30 \mathrm{~min}$, and subsequently cooled for $10 \mathrm{~min}$ in an ice-water bath. After centrifuging the samples at 3,000 rpm for 15 min $\left(5^{\circ} \mathrm{C}\right)$ using a ST 
40R centrifuge (Thermo Fisher Scientific, Osterode, Germany), the absorbance of was measured at $532 \mathrm{~nm}$ with a UV-2005 spectrophotometer (J.P. Selecta, Barcelona, Spain) against a blank prepared with $1 \mathrm{~mL}$ deionized water and $2 \mathrm{~mL}$ TBA/TCA solution. The malondialdehyde (MDA) concentration of each sample was determined against an external standard curve constructed using tetraethoxypropane. The results were expressed as mg MDA per $\mathrm{kg}$ of sausages.

\section{Statistical Analysis}

The complete experiment was repeated three times in a completely randomized design and duplicate samples were drawn for each parameter. The data were subjected to one-way analysis of variance (ANOVA) and Tukey's comparison of the means test $(p \leq 0.05)$ using Minitab 17 software. Data obtained from sensory analysis was analyzed using the Friedman test.

\section{Results and Discussion}

\section{FT-IR Analysis}

Fig. 1 shows the FT-IR spectra of developed garlic inulin and commercial chicory inulin powders. Very identical FT-IR spectra were observed for laboratory prepared garlic inulin powder and commercial inulin powder. Previous studies reported that inulin had distinctive hydroxyl (OH) groups at $3353 \mathrm{~cm}^{-1}$ (Wu and Lee, 2000) and at 3384-3386 $\mathrm{cm}^{-1}$ (Mudannayake et al., 2015b), and $\mathrm{C}=\mathrm{O}$ at $1745 \mathrm{~cm}^{-1}$ (Wu andLee, 2000) and 1631-1640 $\mathrm{cm}^{-1}$ (Mudannayake et al., 2015b) in FT-IR analysis. In the present study, the FT-IR spectrum of garlic inulin had absorption bands at 3339,1457,1130, and $970 \mathrm{~cm}^{-1}$. The peaks at 970 and $1130 \mathrm{~cm}^{-1}$ indicated the presence of inulin (Grube et al., 2002). The absorption bands in the range of $3417-2924 \mathrm{~cm}^{-1}$ 
251 showed the $\mathrm{OH}$ groups which are abundant in inulin structure while those in the range of 1635-

$2521427 \mathrm{~cm}^{-1}$ are responsible for the presence of esterified carboxyl groups. These confirmed similar

253 chemical structure in inulin from both sources. Furthermore, FT-IR results of the current study 254 are comparable to those of chicory, Jerusalem artichoke, globe artichoke and garlic inulin (AbouArab et al., 2011; López-Molina et al., 2005; Wu andLee, 2000).

\section{Inulin content in garlic and commercial inulin powders}

Commercial chicory inulin powder contained a higher content of inulin $(73.43 \%$ dry wt) compared to laboratory prepared garlic inulin powder (63.28\% dry wt) (Table 2$)$ as measured by enzymatic spectrophotometric method (AOAC 999.03). However, the reported amount of inulin (90\% dry wt) in commercial chicory inulin powder as per the product sheet of Orafti GR (2007) is comparatively higher than the actual quantity of inulin measured enzymatically $(73.43 \%$ dry wt) in this study. Mudannayake et al. (2015b) attributed such variations between the commercially reported values and the actual measured values to differences in sample preparation and methods of analysis. In addition, a higher level of purity in garlic inulin may be achieved through application of further purification steps such as activated carbon treatment for extracted garlic juice.

\section{Experiment-1}

\section{Proximate composition of inulin powders}

The moisture, protein, fat and ash contents of the developed garlic inulin and commercial chicory inulin powders are presented in Table 2. Laboratory prepared garlic inulin powder had lower levels of crude fat and crude protein and higher levels of moisture and ash opposed to 
commercial inulin powder $(p<0.05)$. The values reported for commercial inulin in this study are not in agreement with those observed by Mudannayake et al. (2015b) in commercial chicory inulin powder. However, Bouaziz et al. (2014) detected almost similar protein content (1.58\%) and a higher of ash content (1.19\%) in commercial chicory inulin compared to the present study. The differences in the chemical composition might be due to the variations in the species plant extraction process, purification process and method of analysis. In addition, these results suggested that the quality of garlic inulin powder needs to be improved through purification of garlic inulin extract using activated carbon and ion exchange resin (IER) treatments (Mudannayake et al., 2015b).

\section{Proximate composition of chicken sausages}

Table 3 shows the proximate composition of chicken sausages as affected by varying levels of garlic and commercial chicory inulin powders. Fat, protein, ash and moisture contents in the sausage samples varied significantly with the incorporation of inulin powder into sausage formulations as a fat replacer, irrespective of the source of inulin.

Sausages with added inulin had lower fat contents than did the control sausages with no added inulin $(p<0.05)$. Replacement of vegetable oil with inulin was the main reason for the observed low fat content in inulin incorporated sausages (Menegas et al., 2013). Additionally, with the increasing levels of inulin in formulations a significant decline in the fat content of sausages was observed, irrespective of the source of inulin. The use of inulin at $0.87 \%-30 \%$ in different types of sausages effectively reduced the fat content of products (Berizi et al., 2017; 
Bis-Souza et al., 2018; Choi et al., 2016; Glisic et al., 2019; Huang et al., 2011; Keenan et al., 2014; Méndez-Zamora et al., 2015; Menegas et al., 2013; Özer, 2019; Prapasuwannakul, 2018).

According to Table 3 , an increase in moisture content was observed in sausages when the oil content was gradually replaced with inulin, irrespective of the source of inulin $(p<0.05)$. However, the effect is more prominent with commercial chicory inulin. The increment in moisture content may be attributed to the capability of inulin to hold more water during preparation and cooking process (El Zeny et al., 2019) due to the presence of hydrophilic groups and the hygroscopic nature of inulin (Alaei et al., 2018). The findings of the present study are in agreement with those reported by several other researchers on effect of substituting fat with inulin on moisture levels in sausages (Berizi et al., 2017; Glisic et al., 2019; Menegas et al., 2013; Özer, 2019). Furthermore, an inverse relationship between fat and moisture contents of sausages formulated with and without inulin was previously observed (de Souza Paglarini et al., 2021; Keenan et al., 2014; Méndez-Zamora et al., 2015; Šojić et al., 2011).

The increased level of substituting vegetable oil with inulin caused an enhancement of protein content in the sausages, irrespective of the inulin source $(p<0.05$; Table 3$)$. However, the effect was more prominent at an inclusion level of $3 \%$ of inulin in sausage formulations. Similarly, studies conducted to evaluate the effect of inulin on quality parameters of different meat products revealed that inulin incorporated samples had higher protein contents than the control samples with no added inulin (Glisic et al., 2019; Méndez-Zamora et al., 2015; Özer, 2019). The increase in protein content in sausages may be due to the substitution of oil with inulin which contained protein levels of $0.70-1.31 \%$.

Table 3 shows that the inclusion of garlic inulin in to chicken sausages up to $3 \%$ had no effect on ash content of chicken sausages as compared with the control sausages $(p>0.05)$. 
317 However, the ash contents were significantly higher in sausages with $2 \%$ and $3 \%$ commercial

318 inulin as opposed to control samples and garlic inulin added sausages $(p<0.05)$. Šojić et al.,

319 (2011) and Huang et al., (2011) stated that that inulin added sausages contained higher ash

320 percentages than samples with no added inulin. This is attributed to the higher ash content of

321 inulin powders which is arising from the plant sources.

322

323

324

325

326

327

328

329

330

331

332

333

334

335

\section{Sensory analysis}

Sensory quality attributes including flavour, colour and odour determine the consumer preference for food products. Sensory scores given to different sensory attributes of chicken sausages prepared substituting oil with inulin is presented in Fig. 2. The results indicate that substituting the oil content with inulin did not affect the colour and juiciness of sausages $(p>0.05)$. However, significant differences were observed between treatments in relation to texture, odour, flavour, fatty flavour and overall acceptability $(p<0.05)$. Hence, based on the sum of ranks of sensory parameters (Data not shown) substitution of vegetable oil with inulin at $2 \%$ was the best level to produce chicken sausage with better acceptability score, irrespective of the inulin source. The increased level of inulin as a fat substitute in chicken sausages enhanced the sensory scores for colour, appearance and texture (Alaei et al., 2018). In contrast, several studies have revealed that inulin did not affect the acceptability of cooked sausages (Cáceres et al., 2004; Luisa García et al., 2006), Chinese-style sausages (Huang et al., 2011) and dry-fermented chicken sausages (Menegas et al., 2013).

Thus, based on the findings of the Experiment-1 it was possible to manufacture chicken sausages with $30.7 \%$ and $40.6 \%$ lower fat contents with higher product acceptability when vegetable oil was substituted with garlic inulin and commercial inulin at $2 \%$ level, respectively. 
Therefore, these two formulations were selected with the control for analysis of meat quality parameters during frozen storage.

\section{Experiment-2}

\section{Change in $\mathrm{pH}$ value under frozen storage}

Table 4 represents the $\mathrm{pH}$ values of chicken sausages as influenced by different formulations and storage period. There was a significant difference in $\mathrm{pH}$ values between the control and inulin incorporated sausages $(p<0.05)$ until $21 \mathrm{~d}$ of storage. Sausages added with garlic inulin (2\%) showed higher $\mathrm{pH}$ values as opposed to control sausages and those added with commercial inulin $(2 \%)$ and this can be attributed to the slightly alkaline nature of garlic. In contrast, addition of inulin and the reduction of fat content had no effect $(p>0.05)$ on the $\mathrm{pH}$ of sausages (Mendoza et al., 2001; Menegas et al., 2013; Muguerza et al., 2002) and minced meat (Furlán et al., 2014).

The $\mathrm{pH}$ values of sausages decreased over the 28-d frozen storage period, particularly in control samples and garlic inulin added samples after $21 \mathrm{~d}(p<0.05$; Table 4$)$. This was probably due to the metabolic activities of psychotropic bacteria and lactic acid bacteria that are considered as the predominant microorganisms in meat products (Borch et al., 1996). Furthermore, ingredients utilized in the formulation (Kim et al., 2011) and interactions between the polysaccharides and polar and non-polar groups of proteins in food via electrostatic association (Choi et al., 2010) may cause for $\mathrm{pH}$ reduction. In general, $\mathrm{pH}$ value of chicken sausages ranged from 6.5 to 5.0 during a 28 -d storage (Kotula and Wang, 1994). The $\mathrm{pH}$ values reported in this study were within this range during the frozen storage. 
Water holding capacity of comminuted meats such as sausages is an important quality attribute parameter particularly because the structure of tissues has already been destroyed during the processing of such products (Lawrie and Ledward, 2006). Table 5 shows the water holding capacity of experimental sausages during frozen storage period. Substitution of vegetable oil with inulin had no effect on the water holding capacity of chicken sausages. In contrast, MéndezZamora et al. (2015) found that inulin as a fat replacer at $15 \%$ and $30 \%$ decreased the water holding capacity of low-fat frankfurter compared to the control. However, the same quality attribute was decreased with the increasing storage period in all experimental sausages. This can be attributed to the decrease in $\mathrm{pH}$ values observed during the frozen storage as lower $\mathrm{pH}$ denatures myofibrils and decrease the water holding capacity (den Hertog-Meischke et al., 1997).

\section{Changes in colour values under frozen storage}

Changes in colour values of sausages were weekly determined for $28 \mathrm{~d}$ under frozen storage (Table 6). All three colour values of sausages were significantly affected by the frozen storage period $(p<0.05)$. In this regards, the lightness $\left(\mathrm{CIE} \mathrm{L}^{*}\right)$ value of control sausages and those enriched with garlic inulin decreased throughout the frozen storage $(p<0.05)$. In contrast, the redness $\left(\mathrm{CIE} \mathrm{a}^{*}\right)$ and yellowness $\left(\mathrm{CIE} \mathrm{b}^{*}\right)$ values increased significantly with increasing storage period, irrespective of the source of inulin. Menegas et al., (2013) reported that sausages became darker during storage; $\mathrm{CIE} \mathrm{a}^{*}$ value increased $(p<0.05)$ meanwhile $\mathrm{CIE} \mathrm{L}^{*}$ and $\mathrm{CIE} \mathrm{b}^{*}$ remained unchanged $(p>0.05)$ during refrigerated storage.

With respect to the effect of inulin enrichment in sausages on color values, sausages incorporated with garlic inulin and commercial inulin had lower CIE $\mathrm{L}^{*}$ values than control 
sausages until d $7(p<0.05)$. Further, the same trend was detected in sausages enriched with garlic inulin as opposed to control until d $28(p<0.05)$. The reduced lightness values in inulin-added low-fat sausages can be attributed to the decrease in the shine that is usually provided by fat (Cáceres et al., 2004; Menegas et al., 2013; Nowak et al., 2007). Cáceres et al. (2004) further revealed that the whitish translucent gel formed by inulin has no dominant color. The findings of the current study are similar to those of the previous studies by Berizi et al. (2017) and Öztürk and Serdaroğlu (2017) who observed lower lightness values in inulin-enriched meat products, emulsion type sausages and chicken meat balls, as opposed to those without enrichment, respectively. In contrast, inulin addition significantly increased the CIE L* values in Chinese style sausages compared to control (Huang et al., 2011).

Šojić et al., (2011) found correlations between the CIE L* value and fat content $(r=0.99$; $p<0.001)$ and also between the CIE $\mathrm{a}^{*}$ value and fat content $(\mathrm{r}=-1.00 ; p<0.001)$. Furthermore, Menegas et al., (2013) noticed a higher redness value in sausage formulation with inulin compared with that with standard oil content. Therefore, an increase in redness value was expected with the decrease in the fat level of sausages. However, significantly higher redness values in inulin-added reduced-fat sausages as opposed to control sausages were only observed in d 1 . From d 14 onward control sausages had higher redness values than inulin-added sausages $(p<0.05)$. Recently, de Souza Paglarini et al., (2021) observed lower redness values in inulin gelincorporated Bologna sausages as opposed to control sausages.

Addition of inulin into sausage formulation had no effect on the yellowness of the product at $\mathrm{d} 1$ ( $p>0.05)$. From $\mathrm{d} 7$ onward CIE $\mathrm{b}^{*}$ value was significantly influenced by the level and source of inulin. In general, sausages added with commercial chicory inulin recorded higher yellowness values than those added with garlic inulin $(p<0.05)$. Comparable yellowness values were 
reported previously in meat products prepared with and without inulin (Berizi et al., 2017; Prapasuwannakul, 2018).

\section{Textural properties of sausages samples}

Texture profile analysis revealed that incorporation of inulin into sausage formulations significantly reduced the hardness (maximum force required to compress the sample) and chewiness (work to masticate the sample for swallowing) $(p<0.05)$. Control sample showed a significantly higher hardness value (1603.7 g) compared with sausages incorporated with commercial inulin $(1165.0 \mathrm{~g})$ and garlic inulin (1237.0 g). Chewiness value for control sample $(47.3 \mathrm{~mJ})$ was significantly greater than that of sausages incorporated with commercial inulin $(32.4 \mathrm{~mJ})$ and garlic inulin $(39.0 \mathrm{~mJ})$. These results are comparable to those obtained by other authors for frankfurters, pork bologna and beef burger incorporated with dietary fiber (GrigelmoMiguel et al., 1999; Mansour and Khalil, 1997; Shand, 2000). Reduced-fat meat products incorporated with inulin were softer than those having conventional levels of fat (Cáceres et al., 2004; Choi et al., 2016; Glisic et al., 2019; Özer, 2019; Prapasuwannakul, 2018) which may reduce the amount of force required to chew samples for swallowing.

However, inulin enrichment did not change other texture parameters of sausages such as springiness, cohesiveness, adhesiveness and gumminess ( $p>0.05$; Data not shown). Similar results were reported by Choi et al. (2016) for restructured sausages incorporated with chicory fiber as a fat replacer. Garcia et al. (2006) reported that differences observed in the texture properties of meat products depend on the type and level of inulin used. When inulin was incorporated as a gel in meat products, textural parameters changed only at a higher level of incorporation ( $7.5 \%$ or more) resulting softer sausages irrespective of the fat content. Therefore, 
432 the addition of lower level of inulin in this study (2\%) might be the reason for comparable values

433 observed for gumminess, cohesiveness, adhesiveness, and springiness of different sausage

434 samples.

\section{Changes of lipid oxidation with the storage time}

To investigate the effect of inulin inclusion on the lipid oxidation of sausages, TBARS values of the sausages were measured. Regardless of the level and source of inulin utilized the TBARS values of sausage samples increased significantly with increasing frozen storage (Table 7). Domínguez et al., (2019) stated that lipid oxidation in meat and meat products are influenced by storage time; with increasing time the possibility of radicals to cause damage to lipids increases. In addition, the release of iron from heme-proteins gets accelerated with long storage periods and it catalyzes multiple reactions in the initiation and propagation phases of lipid oxidation.

In addition, both garlic inulin and chicory inulin-added sausages showed lower TBARS values than control sausages throughout the storage period. This could be due to the differences in fat content of the experimental sausages, as shown in the Table 3. It has been previously reported that TBARS values near $0.5 \mathrm{mg} \mathrm{kg}^{-1}$ sample are indicative of the beginning of oxidation, whereas those above $1.0 \mathrm{mg} \mathrm{kg}^{-1}$ sample suggest advanced oxidative status (Reitznerová et al., 2017). In the present study, all experimental sausages had TBARS values lower than sensory rancidity detection $(<1.0)$. 


\section{Conclusion}

This study was conducted with the aim of evaluating the sensory and physicochemical properties of inulin incorporated low-fat chicken sausages. Overall, the findings showed that fat content of the sausages can be reduced from $13.67 \%$ (Control sample) to $4.47-4.85 \%$ by incorporating water-based inulin gel to the product formula at the level of $3 \%$ inulin. However, $2 \%$ garlic inulin contributed to better sensory qualities such as flavour and overall acceptability. In addition, protein, ash and moisture contents of the sausage samples were increased when inulin percentage was increased in the formulation. Hence, garlic inulin can be used to successfully substitute fat in sausage production without altering the meat quality parameters.

\section{References}

Abou-Arab AA, Talaat H, Abu-Salem F. 2011. Physico-chemical properties of inulin produced from Jerusalem artichoke tubers on bench and pilot plant scale. Aust J Basic Appl Sci 5: 1297-1309.

Alaei F, Hojjatoleslamy M, Hashemi Dehkordi SM. 2018. The effect of inulin as a fat substitute on the physicochemical and sensory properties of chicken sausages. Food Sci Nutr 6:512519. https://doi.org/10.1002/fsn3.585

AOAC. (2005). Official methods of analysis of AOAC International. (18th ed.). Maryland, USA: AOAC International.

AOAC. (2016). Official methods of analysis of AOAC Internatioanl. (20th ed.). Washington, USA: AOAC International. 
Berizi E, Shekarforoush S, Mohammadinezhad S, Hosseinzadeh S, Farahnaki A. 2017. The use of inulin as fat replacer and its effect on texture and sensory properties of emulsion type sausages. Iran J Vet Res 18(4):253-257.

Bis-Souza CV, Henck JMM, Barretto ACDS. 2018. Performance of low-fat beef burger with added soluble and insoluble dietary fibers. J Food Sci Technol 38:522-529. https://doi.org/10.1590/fst.09217

Borch E, Kant-Muermans ML, Blixt Y. 1996. Bacterial spoilage of meat and cured meat products. Int J Food Microbiol 33(1):103-120. https://doi.org/10.1016/0168-1605(96)01135$\underline{X}$

Bouaziz MA, Rassaoui R, Besbes S. 2014. Chemical composition, functional properties, and effect of inulin from tunisian Agave americana L. leaves on textural qualities of pectin gel. J Chem 2014:758697. https://doi.org/10.1155/2014/758697

Cáceres E, Garcia M, Toro J, Selgas M. 2004. The effect of fructooligosaccharides on the sensory characteristics of cooked sausages. Meat Sci, 68(1):87-96. https://doi.org/10.1016/j.meatsci.2004.02.008

Choi HS, Choi HG, Choi YS, Kim JH, Lee JH, Jung EH, Lee SH, Choi YI, Choi JS. 2016. Effect of chicory fiber and smoking on quality characteristics of restructured sausages. Korean J Food Sci An 36(1):131-136. https://dx.doi.org/10.5851\%2Fkosfa.2016.36.1.131

Choi YS, Choi JH, Han DJ, Kim HY, Lee MA, Jeong JY, Chung HJ, Kim CJ. 2010. Effects of replacing pork back fat with vegetable oils and rice bran fiber on the quality of reduced-fat frankfurters. Meat Sci 84(3):557-563. https://doi.org/10.1016/j.meatsci.2009.10.012 de Souza Paglarini C, Vidal VA, Ribeiro W, Badan Ribeiro AP, Bernardinelli OD, Herrero AM, Ruiz-Capillas C, Sabadini E, Rodrigues Pollonio MA. 2021. Using inulin-based emulsion 
gels as fat substitute in salt reduced Bologna sausage. J Sci Food Agric 101:505-517. https://doi.org/10.1002/jsfa.10659

den Hertog-Meischke M, Van Laack R, Smulders F. 1997. The water-holding capacity of fresh meat. Vet Q 19(4):175-181. https://doi.org/10.1080/01652176.1997.9694767

Domingo JL, Nadal M. 2017. Carcinogenicity of consumption of red meat and processed meat: A review of scientific news since the IARC decision. Food Chem Toxicol 105:256-261. https://doi.org/10.1016/j.fct.2017.04.028

Domínguez R, Pateiro M, Gagaoua M, Barba FJ, Zhang W, Lorenzo JM. 2019. A comprehensive review on lipid oxidation in meat and meat products. Antioxidants 8(10):429. https://doi.org/10.3390/antiox8100429

El Zeny T, Essa RY, Bisar BA, Metwalli S. 2019. Effect of using chicory roots powder as a fat replacer on beef burger quality. Slov Vet Res 56(Suppl. 22):509-514. https://doi.org/10.26873/SVR-788-2019

Franck A. 2002. Technological functionality of inulin and oligofructose. Br J Nutr 87(S2):S287S291. https://doi.org/10.1079/BJN/2002550

Furlán LTR, Padilla AP, Campderrós ME. 2014. Development of reduced fat minced meats using inulin and bovine plasma proteins as fat replacers. Meat Sci 96(2):762-768. https://doi.org/10.1016/j.meatsci.2013.09.015

Glisic M, Baltic M, Glisic M, Trbovic D, Jokanovic M, Parunovic N, Dimitrijevic M, Suvajdzic B, Boskovic M, Vasilev D. 2019. Inulin-based emulsion-filled gel as a fat replacer in prebiotic-and PUFA-enriched dry fermented sausages. Int J Food Sci Technol 54(3):787797. https://doi.org/10.1111/ijfs. 13996 
Grigelmo-Miguel N, Abadías-Serós MAI, Martín-Belloso O. 1999. Characterisation of low-fat high-dietary fibre frankfurters. Meat Sci 52(3):247-256. https://doi.org/10.1016/S0309$\underline{1740(98) 00173-9}$

Grube M, Bekers M, Upite D, Kaminska E. 2002. IR-spectroscopic studies of Zymomonas mobilis and levan precipitate. Vib Spectrosc 28(2):277-285. https://doi.org/10.1016/S0924$\underline{2031(02) 00005-X}$

Guedes-Oliveira JM, Costa-Lima BR, Oliveira D, Neto A, Deliza R, Conte-Junior CA, Guimarães CFM. 2019. Mixture design approach for the development of reduced fat lamb patties with carboxymethyl cellulose and inulin. Food Sci Nutr 7(4):1328-1336. https://doi.org/10.1002/fsn3.965

Hamm R. 1961. Biochemistry of meat hydration. In Advances in food research. Chichester CO, Mrak EM (ed). Academic Press, New York. pp 355-463. https://doi.org/10.1016/S0065$\underline{2628(08) 60141-X}$

Han M, Bertram HC. 2017. Designing healthier comminuted meat products: Effect of dietary fibers on water distribution and texture of a fat-reduced meat model system. Meat Sci 133:159-165. https://doi.org/10.1016/j.meatsci.2017.07.001

Hathwar SC, Rai AK, Modi VK, Narayan B. 2012. Characteristics and consumer acceptance of healthier meat and meat product formulations—a review. J Food Sci Technol 49(6):653-664. https://doi.org/10.1007/s13197-011-0476-Z

Higgs JD. 2000. The changing nature of red meat: 20 years of improving nutritional quality. Trends Food Sci Technol 11(3):85-95. https://doi.org/10.1016/S0924-2244(00)00055-8 
Huang S, Tsai Y, Chen C. 2011. Effects of wheat fiber, oat fiber, and inulin on sensory and physico-chemical properties of Chinese-style sausages. Asian-Australas J Anim Sci 24(6):875-880. https://doi.org/10.5713/ajas.2011.10317

Illippangama AU, Jayasena DD, Jo C, Mudannayake DC. 2022. Inulin as a functional ingredient and their applications in meat products. Carbohydr Polym 275:118706. https://doi.org/10.1016/j.carbpol.2021.118706

Keenan DF, Resconi VC, Kerry JP, Hamill RM. 2014. Modelling the influence of inulin as a fat substitute in comminuted meat products on their physico-chemical characteristics and eating quality using a mixture design approach. Meat Sci 96(3):1384-1394. https://doi.org/10.1016/j.meatsci.2013.11.025

Kim TH, Choi JH, Choi YS, Kim HY, Kim SY, Kim HW, Kim,CJ. 2011. Physicochemical properties of thawed chicken breast as affected by microwave power levels. Food Sci Biotechnol 20(4):971. https://doi.org/10.1007/s10068-011-0134-2

Kim Y, Wang S. 2001. Kinetic study of thermally induced inulin gel. J Food Sci 66(7):991-997. https://doi.org/10.1111/j.1365-2621.2001.tb08224.x

Kotula KL, Wang Y. 1994. Characterization of broiler meat quality factors as influence by feed withdrawal time. J Appl Poult Res 3(2):103-110. https://doi.org/10.1093/japr/3.2.103

Lawrie RA, Ledward DA. 2006. The storage and preservation of meat. I. Temperature control. In Lawrie's Meat Science (7th ed.). CRC Press, Boca Raton. pp 189-234. https://doi.org/10.1533/9781845691615.189

Lee D, Lee HJ, Yoon JW, Ryu M, Jo C. 2021. Effects of cooking conditions on the physicochemical and sensory characteristics of dry- and wet-aged beef. Anim Biosci 34:1705-1716. 
López-Molina D, Navarro-Martínez MD, Rojas-Melgarejo F, Hiner AN, Chazarra S, RodríguezLópez JN. 2005. Molecular properties and prebiotic effect of inulin obtained from artichoke (Cynara scolymus L.). Phytochemistry 66(12):1476-1484. https://doi.org/10.1016/j.phytochem.2005.04.003

Luisa García M, Cáceres E, Dolores Selgas M. 2006. Effect of inulin on the textural and sensory properties of mortadella, a Spanish cooked meat product. Int J Food Sci Technol 41(10):1207-1215. https://doi.org/10.1111/j.1365-2621.2006.01186.x

Mansour EH, Khalil AH. 1997. Characteristics of low-fat beefburger as influenced by various types of wheat fibers. Food Res Int 30(3-4):199-205. https://doi.org/10.1016/S0963$\underline{9969(97) 00043-4}$

McCleary B, Murphy A, Mugford DC. 2000. Measurement of total fructan in foods by enzymatic/spectrophotometric method: collaborative study. J AOAC Int 83(2):356-364. https://doi.org/10.1093/jaoac/83.2.356

Melilli MG, Costa C, Lucera A, Padalino L, Del Nobile MA, Conte A. 2021. Fiordilatte Cheese Fortified with Inulin from Cichorium intybus or Cynara cardunculus. Foods 10(6):1215. https://doi.org/10.3390/foods10061215

Méndez-Zamora G, García-Macías JA, Santellano-Estrada E, Chávez-Martínez A, DuránMeléndez LA, Silva-Vázquez R, Quintero-Ramos A. 2015. Fat reduction in the formulation of frankfurter sausages using inulin and pectin. J Food Sci Technol 35:25-31. https://doi.org/10.1590/1678-457X.6417

Mendoza E, Garcia M, Casas C, Selgas M. 2001. Inulin as fat substitute in low fat, dry fermented sausages. Meat Sci 57(4):387-393. https://doi.org/10.1016/S0309-1740(00)00116-9 
Menegas LZ, Pimentel TC, Garcia S, Prudencio SH. 2013. Dry-fermented chicken sausage produced with inulin and corn oil: Physicochemical, microbiological, and textural characteristics and acceptability during storage. Meat Sci 93(3):501-506. https://doi.org/10.1016/j.meatsci.2012.11.003

Mensink MA, Frijlink HW, van der Voort Maarschalk K, Hinrichs WL. 2015. Inulin, a flexible oligosaccharide. II: Review of its pharmaceutical applications. Carbohydr Polym 134: 418428. https://doi.org/10.1016/j.carbpol.2015.08.022

Moongngarm A, Trachoo N, Sirigungwan N. 2011. Low molecular weight carbohydrates, prebiotic content, and prebiotic activity of selected food plants in Thailand. Adv J Food Sci Technol 3(4):269-274.

Mudannayake DC, Wimalasiri KM, Silva KF, Ajlouni S. 2015a. Selected Sri Lankan food plants and other herbs as potential sources of inulin-type fructans. J Natl Sci Found Sri Lanka 43(1):35-43. http://dx.doi.org/10.4038/jnsfsr.v43i1.7913

Mudannayake DC, Wimalasiri KM, Silva KF, Ajlouni, S. 2015b. Comparison of properties of new sources of partially purified inulin to those of commercially pure chicory inulin. J Food Sci 80(5):C950-C960. https://doi.org/10.1111/1750-3841.12857

Muguerza E, Fista G, Ansorena D, Astiasarán I, Bloukas J. 2002. Effect of fat level and partial replacement of pork backfat with olive oil on processing and quality characteristics of fermented sausages. Meat Sci 61(4):397-404. https://doi.org/10.1016/S0309$\underline{1740(01) 00210-8}$

Nowak B, Heise A, Tarnowski N, Von Mueffling T. 2007. Microbiological and color aspects of cooked sausages made from a standardized porcine blood cell concentrate. J. Food Prot 70(5):1181-1186. https://doi.org/10.4315/0362-028X-70.5.1181 
Oswell NJ, Gunstone FD, Pegg RB. (2005). Vegetable oils. In: Bailey's Industrial Oil and Fat Products, F. Shahidi (Ed.). 1-30. https://doi.org/10.1002/047167849X.bio018.pub2

Özer C. 2019. Utilization of Jerusalem artichoke powder in production of low-fat and fat-free fermented sausage. Ital J Food Sci 31(2):301-310. https://doi.org/10.14674/IJFS-1354

Öztürk B, Serdaroğlu M. 2017. A rising star prebiotic dietary fiber: inulin and recent applications in meat products. Food Health 3(1):12-20. . https://doi.org/10.3153/JFHS17002

Pereira PMDCC, Vicente AFDRB. 2013. Meat nutritional composition and nutritive role in the human diet. Meat Sci 93(3):586-592. https://doi.org/10.1016/j.meatsci.2012.09.018

Prapasuwannakul N. 2018. Characteristics of reduced-fat thai pork sausage with inulin addition. Int J Food Eng 4(4):322-326. https://doi.org/10.18178/ijfe.4.4.322-326

Reitznerová A, Šuleková M, Nagy J, Marcinčák S, Semjon B, Čertík M, Klempová T. (2017). Lipid peroxidation process in meat and meat products: a comparison study of malondialdehyde determination between modified 2-thiobarbituric acid spectrophotometric method and reverse-phase high-performance liquid chromatography. Molecules 22(11):1988. https://doi.org/10.3390/molecules22111988

Shand P. 2000. Textural, water holding, and sensory properties of low-fat pork bologna with normal or waxy starch hull-less barley. J Food Sci 65(1):101-107. https://doi.org/10.1111/j.1365-2621.2000.tb15963.x

Šojić BV, Petrović LS, Pešović BM, Tomović VM, Jokanović MR, Džinić NR, Salitrežić PP. 2011. The influence of inulin addition on the physico-chemical and sensory characteristics of reduced-fat cooked sausages. Acta Period Technol 42:157-164. https://doi.org/10.2298/APT1142157S 
Verbeke W, Pérez-Cueto FJ, de Barcellos MD, Krystallis A, Grunert KG. 2010. European citizen and consumer attitudes and preferences regarding beef and pork. Meat Sci 84(2):284-292. https://doi.org/10.1016/j.meatsci.2009.05.001

Weiss J, Gibis M, Schuh V, Salminen H. 2010. Advances in ingredient and processing systems for meat and meat products. Meat Sci 86(1):196-213. https://doi.org/10.1016/j.meatsci.2010.05.008

Wilhelm AE, Maganhini MB, Hernández-Blazquez FJ, Ida EI, Shimokomaki M. 2010. Protease activity and the ultrastructure of broiler chicken PSE (pale, soft, exudative) meat. Food Chem 119(3):1201-1204. https://doi.org/10.1016/j.foodchem.2009.08.034

Wolk A. 2017. Potential health hazards of eating red meat. J Intern Med 281(2):106-122. https://doi.org/10.1111/joim.12543

Wu XY, Lee PI. 2000. Preparation and characterization of inulin ester microspheres as drug carriers. J Appl Polym Sci 77(4):833-840. https://doi.org/10.1002/(SICI)10974628(20000725)77:4\%3C833::AID-APP17\%3E3.0.CO;2-4 


\section{Figure Legends}

645

646 Fig. 1. FTIR spectra of garlic inulin and commercial inulin

647 Fig. 2. Radar chart for sensory evaluation to select the best sausages samples.

648

649 


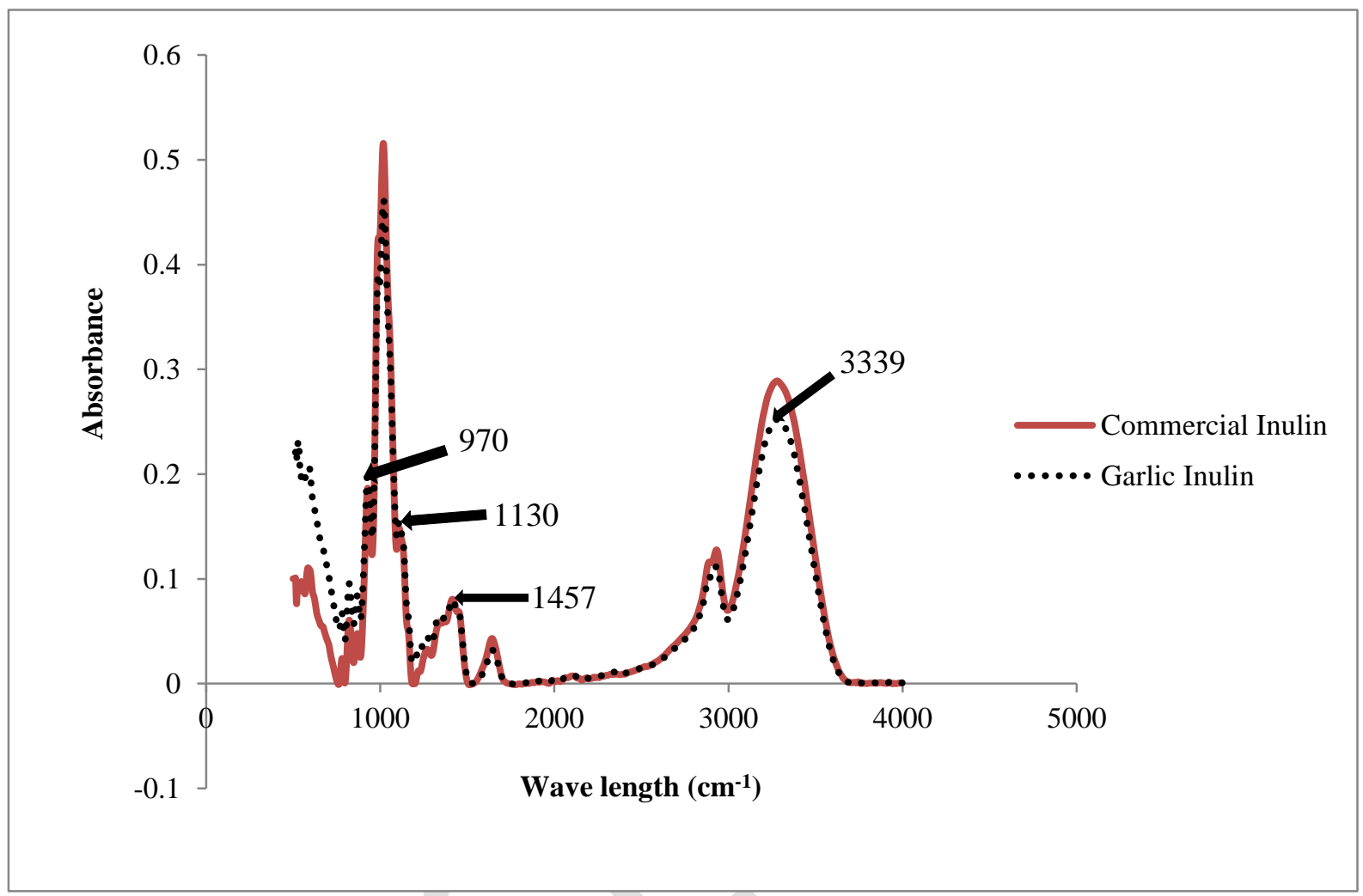

651

652 Fig. 1.

653 


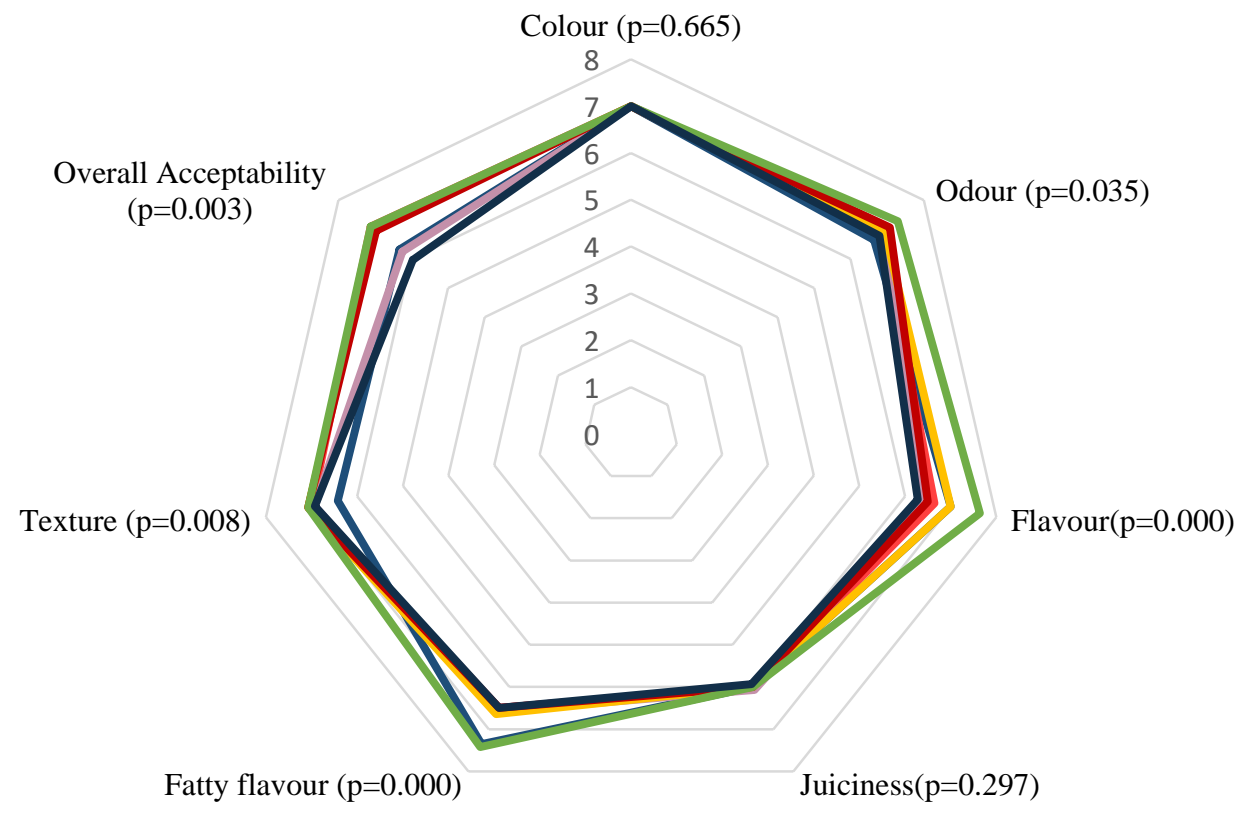

Garlic Inulin 1\% Commercial Inulin 2\% Commercial Inulin 3\%

Control Sample Commercial Inulin 1\% Carlic Inulin 2\%

654

Garlic Inulin 3\%

655

Fig. 2.

656 
List of Tables

658 Table 1. Percentage ingredients used for the production of low-fat chicken sausages

\begin{tabular}{|c|c|c|c|c|c|c|c|}
\hline \multirow[t]{2}{*}{ Ingredients } & \multicolumn{7}{|c|}{ Formulations (\% of ingredients)* } \\
\hline & Control & GI $1 \%$ & GI $2 \%$ & GI 3\% & CI $1 \%$ & CI $2 \%$ & CI 3\% \\
\hline Chicken breast meat & 71 & 71 & 71 & 71 & 71 & 71 & 71 \\
\hline Vegetable oil & 3 & 2 & 1 & 0 & 2 & 1 & 0 \\
\hline Garlic inulin gel & 0 & 1 & 2 & 3 & 0 & 0 & 0 \\
\hline Commercial inulin gel & 0 & 0 & 0 & 0 & 1 & 2 & 3 \\
\hline Wheat flour & 6 & 6 & 6 & 6 & 6 & 6 & 6 \\
\hline Ice flakes & 15 & 15 & 15 & 15 & 15 & 15 & 15 \\
\hline Chili powder & 1.5 & 1.5 & 1.5 & 1.5 & 1.5 & 1.5 & 1.5 \\
\hline Salt & 1.5 & 1.5 & 1.5 & 1.5 & 1.5 & 1.5 & 1.5 \\
\hline Pepper & 0.5 & 0.5 & 0.5 & 0.5 & 0.5 & 0.5 & 0.5 \\
\hline Onion & 1.2 & 1.2 & 1.2 & 1.2 & 1.2 & 1.2 & 1.2 \\
\hline Cardamom & 0.15 & 0.15 & 0.15 & 0.15 & 0.15 & 0.15 & 0.15 \\
\hline Cinnamon & 0.15 & 0.15 & 0.15 & 0.15 & 0.15 & 0.15 & 0.15 \\
\hline
\end{tabular}


661 Table 2. Chemical constituent composition (\%) of garlic and commercial inulin powders

\begin{tabular}{|c|c|c|c|}
\hline Constituents (\%) & Garlic inulin powder & Commercial inulin powder & SEM $^{1}$ \\
\hline Moisture & $5.10^{\mathrm{A}}$ & $3.62^{\mathrm{B}}$ & 0.369 \\
\hline Ash & $0.94^{\mathrm{A}}$ & $0.68^{\mathrm{B}}$ & 0.059 \\
\hline Crude protein & $0.70^{\mathrm{B}}$ & $1.31^{\mathrm{A}}$ & 0.154 \\
\hline Crude fat & $0.55^{\mathrm{B}}$ & & 0.029 \\
\hline Inulin & $63.28^{\mathrm{B}}$ & 73. & 2.36 \\
\hline
\end{tabular}

664 
665 Table 3. Proximate composition of chicken sausages as affected by different sources and 666 levels of inulin.

\begin{tabular}{lcccccccc}
\hline Constituents & \multicolumn{7}{c}{ Formulations $^{1}$} & SEM $^{2}$ \\
\cline { 2 - 7 }$(\%)$ & Control & GI 1\% & GI 2\% & GI 3\% & CI 1\% & CI 2\% & CI 3\% & \\
\hline Fat & $13.67^{\mathrm{A}}$ & $12.89^{\mathrm{AB}}$ & $9.47^{\mathrm{C}}$ & $4.85^{\mathrm{D}}$ & $11.97^{\mathrm{B}}$ & $8.12^{\mathrm{C}}$ & $4.47^{\mathrm{D}}$ & 0.779 \\
Moisture & $63.33^{\mathrm{D}}$ & $66.11^{\mathrm{CD}}$ & $67.10^{\mathrm{BC}}$ & $69.74^{\mathrm{B}}$ & $69.20^{\mathrm{BC}}$ & $73.59^{\mathrm{A}}$ & $74.30^{\mathrm{A}}$ & 0.846 \\
Ash & $1.01^{\mathrm{C}}$ & $1.12^{\mathrm{C}}$ & $1.17^{\mathrm{BC}}$ & $1.20^{\mathrm{BC}}$ & $1.19^{\mathrm{BC}}$ & $1.38^{\mathrm{B}}$ & $2.24^{\mathrm{A}}$ & 0.087 \\
Protein & $9.65^{\mathrm{C}}$ & $9.97^{\mathrm{BC}}$ & $10.24^{\mathrm{ABC}}$ & $10.76^{\mathrm{A}}$ & $10.09^{\mathrm{ABC}}$ & $10.24^{\mathrm{ABC}}$ & $10.44^{\mathrm{AB}}$ & 0.086
\end{tabular}

667 A-D Values in the same row with different superscripts differ significantly $(p<0.05)$.

$668{ }^{1}$ GI- Garlic inulin; CI- Commercial inulin.

$669{ }^{2}$ Pooled standard error of mean $(\mathrm{n}=21)$.

670 
671 Table 4. Effect of different inulin sources on the $\mathbf{p H}$ value of low-fat chicken sausages

672 during storage.

673

\begin{tabular}{|c|c|c|c|c|}
\hline \multirow{2}{*}{ Period } & \multicolumn{3}{|c|}{ Formulations } & \multirow{2}{*}{ SEM $^{1}$} \\
\hline & Control & Garlic inulin & Commercial inulin & \\
\hline Day 1 & $6.18^{\mathrm{Ay}}$ & $6.36^{\mathrm{Ax}}$ & $6.16^{\mathrm{Ay}}$ & 0.032 \\
\hline Day 7 & $6.14^{\mathrm{Ay}}$ & $6.34^{\mathrm{Ax}}$ & $6.05^{\mathrm{Az}}$ & 0.043 \\
\hline Day 14 & $6.12^{\mathrm{Ay}}$ & $6.24^{\mathrm{ABx}}$ & $04^{\mathrm{A}}$ & 0.029 \\
\hline Day 21 & $6.10^{\mathrm{ABx}}$ & $\mathrm{BCx}^{\mathrm{B}}$ & $6.02^{\mathrm{Ay}}$ & 0.016 \\
\hline Day 28 & $5.96^{\mathrm{Bx}}$ & $\mathrm{Cx}$ & $6.00^{\mathrm{Ax}}$ & 0.045 \\
\hline SEM $^{2}$ & 0.023 & 0.030 & 0.022 & \\
\hline \multicolumn{5}{|c|}{$\begin{array}{l}\text { A-C Values in the same column with different superscripts differ significantly }(p<0 \text {. } \\
{ }^{\mathrm{x}-\mathrm{z}} \text { Values in the same row with different superscripts differ significantly }(p<0.05) \text {. } \\
{ }^{1} \text { Pooled standard error of mean }(\mathrm{n}=9) \text {. }\end{array}$} \\
\hline
\end{tabular}



during storage.

681

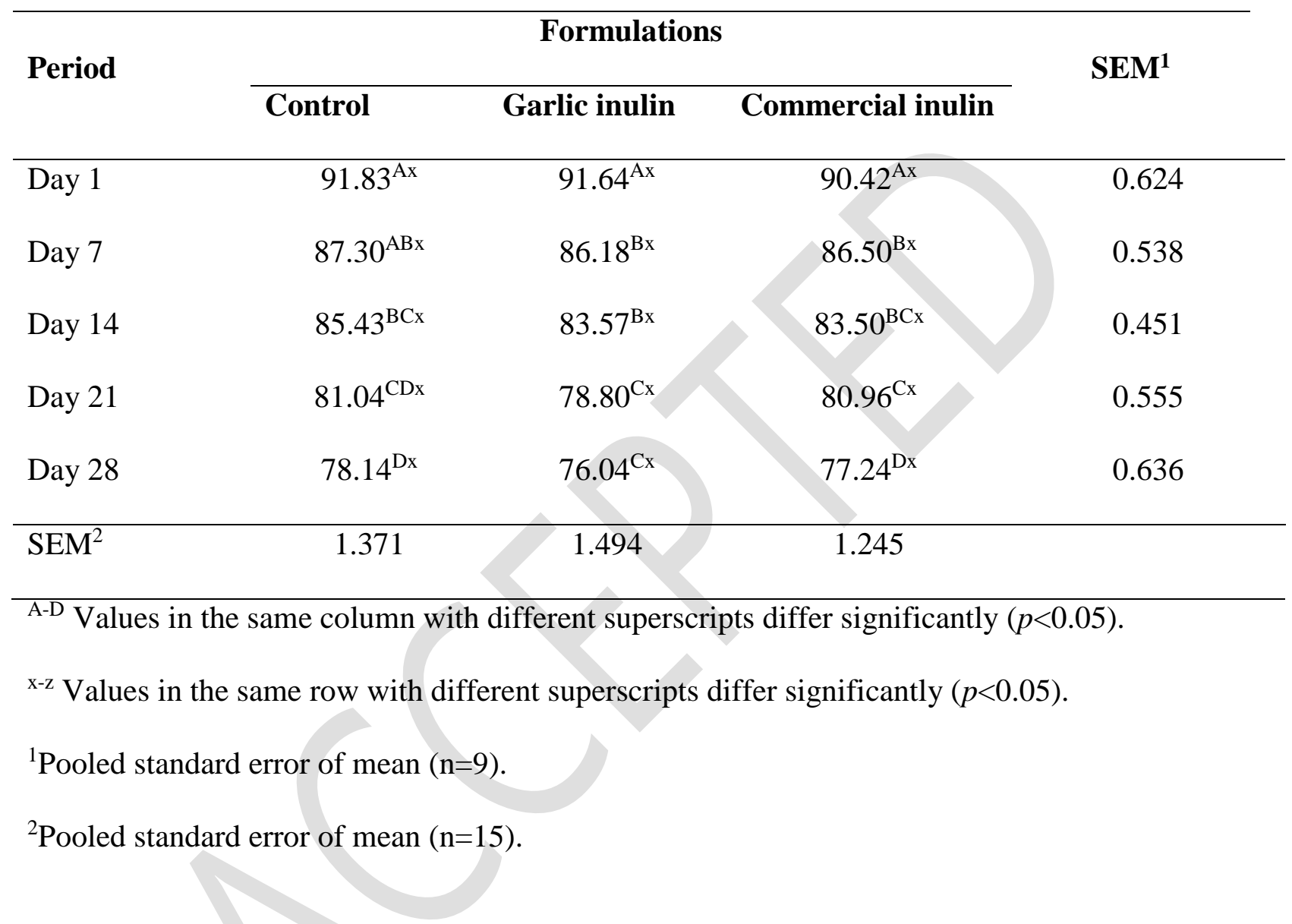



sausages during storage.

\begin{tabular}{|c|c|c|c|c|}
\hline \multirow{2}{*}{ Period } & \multicolumn{3}{|c|}{ Formulations } & \multirow{2}{*}{ SEM $^{1}$} \\
\hline & Control & Garlic inulin & Commercial inulin & \\
\hline \multicolumn{5}{|l|}{ CIE L* } \\
\hline Day 1 & $68.87^{\mathrm{Ax}}$ & $65.75^{\mathrm{Ay}}$ & $65.97^{\mathrm{Ay}}$ & 0.513 \\
\hline Day 7 & $68.30^{\mathrm{Ax}}$ & $65.41^{\mathrm{Ay}}$ & $65.86^{\mathrm{Az}}$ & 0.450 \\
\hline Day 14 & $65.98^{\mathrm{Bx}}$ & $63.26^{\text {By }}$ & $65.74^{\mathrm{Ax}}$ & 0.450 \\
\hline Day 21 & $65.49^{\mathrm{Bx}}$ & & $65.50^{\mathrm{Ax}}$ & 0.404 \\
\hline Day 28 & $64.73^{\mathrm{Cy}}$ & & $65.21^{\mathrm{Ax}}$ & 0.308 \\
\hline $\mathrm{SEM}^{2}$ & 0.436 & 0.315 & 0.121 & \\
\hline \multicolumn{5}{|l|}{ CIE a* } \\
\hline Day 1 & $11.51^{\mathrm{Cy}}$ & $12.07^{\mathrm{Cx}}$ & $11.73^{\text {Cxy }}$ & 0.104 \\
\hline Day 7 & $12.61^{\mathrm{Bx}}$ & $12.71^{\mathrm{Bx}}$ & $12.73^{B x}$ & 0.028 \\
\hline Day 14 & $14.09^{\mathrm{Ax}}$ & $13.55^{\mathrm{Ay}}$ & $12.88^{\mathrm{Bz}}$ & 0.181 \\
\hline Day 21 & $14.24^{\mathrm{Ax}}$ & $13.60^{\mathrm{Ay}}$ & $13.67^{\mathrm{Ay}}$ & 0.108 \\
\hline Day 28 & $14.26^{\mathrm{Ax}}$ & $13.67^{\mathrm{Ay}}$ & $13.86^{\text {Axy }}$ & 0.099 \\
\hline $\mathrm{SEM}^{2}$ & 0.297 & 0.172 & 0.206 & \\
\hline
\end{tabular}


CIE b*

\begin{tabular}{|c|c|c|c|c|}
\hline Day 1 & $32.71^{\mathrm{Cx}}$ & $32.75^{\mathrm{Cx}}$ & $33.31^{\mathrm{Cx}}$ & 0.140 \\
\hline Day 7 & $33.83^{\mathrm{By}}$ & $33.46^{\mathrm{By}}$ & $34.34^{\mathrm{Bx}}$ & 0.137 \\
\hline Day 14 & $36.45^{\mathrm{Ax}}$ & $34.83^{\mathrm{Ay}}$ & $34.58^{\text {By }}$ & 0.299 \\
\hline Day 21 & $37.13^{\mathrm{Ax}}$ & $34.85^{\mathrm{Ay}}$ & $36.93^{\mathrm{Ax}}$ & 0.382 \\
\hline Day 28 & $37.35^{\mathrm{Ax}}$ & $34.91^{\mathrm{Ay}}$ & $37.27^{\mathrm{Ax}}$ & 0.413 \\
\hline $\mathrm{SEM}^{2}$ & 0.507 & 0.245 & .419 & \\
\hline
\end{tabular}


694 chicken sausages during storage.

\begin{tabular}{lcccc}
\hline \multirow{2}{*}{ Period } & \multicolumn{3}{c}{ Formulations } & SEM $^{\mathbf{3}}$ \\
\cline { 2 - 4 } & Control & Garlic inulin & Commercial inulin & 0.003 \\
\hline Day 1 & $0.056^{\mathrm{Cx}}$ & $0.039^{\mathrm{Ey}}$ & $0.036^{\mathrm{Cy}}$ & 0.004 \\
Day 7 & $0.071^{\mathrm{Cx}}$ & $0.053^{\mathrm{Dy}}$ & $0.046^{\mathrm{Cz}}$ & 0.009 \\
Day 14 & $0.136^{\mathrm{Bx}}$ & $0.088^{\mathrm{Cy}}$ & $0.089^{\mathrm{By}}$ & 0.012 \\
Day 21 & $0.171^{\mathrm{Bx}}$ & $0.130^{\mathrm{Bxy}}$ & $0.099^{\mathrm{By}}$ & 0.014 \\
Day 28 & $0.226^{\mathrm{Ax}}$ & $0.154^{\mathrm{Ay}}$ & $0.145^{\mathrm{Ay}}$ & 0.0014
\end{tabular}

$\begin{array}{llll}\mathrm{SEM}^{2} & 0.017 & 0.012 & 0.011\end{array}$

A-E Values in the same column with different superscripts differ significantly $(p<0.05)$.

$696{ }^{x-z}$ Values in the same row with different superscripts differ significantly $(p<0.05)$.

$697{ }^{1}$ Standard error of mean $(n=9)$.

$698 \quad{ }^{2}$ Standard error of mean $(n=15)$.

699 